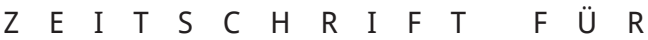

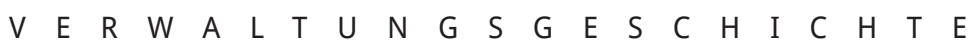

B A N D $3, \quad 2 \quad 0 \quad 18$

$S$ E I T E $5-19$

D O I : $10.2478 / \mathrm{ADH}$ I- $2018-0029$

\title{
Bureaucracy and Emotions - Perspectives across Disciplines
}

PETER COLLIN, ROBERT GAROT, TIMON DE GROOT

The focus of this volume of Administory is on the role of emotions in public administration. There are two main reasons for choosing this issue. On the one hand, an »emotional turn « has been taking place in the field of history for quite some time, ${ }^{1}$ which administrative history does not unconditionally follow, but for whose suggestions it should be open. On the other hand - and this is the more specific reason - the topic of remotions administration because in traditional administrative models, the public servant is emotionally conceptualized in a specific way, namely, as a rationally acting and emotionally abstinent person.

With this conjecture, one could stop. As far as administrative history deals with emotions, we might limit ourselves to grappling with their suppression. However, such a conceptualized administrative history would ignore reality because - as is widely recognized in contemporary psychology ${ }^{2}$ - cognitive and emotional processes cannot be analysed separately. It should also be borne in mind that the term semotion covers an enormous variety of psychic states. What exactly belongs to it and what does not is controversial in detail; the edges are blurred. It is not the purpose of this introduction to comprehend this discussion. However if, for example, the "sense of duty" is counted among emotions, ${ }^{3}$ then even traditional administrative concepts are not exclusively tied to negative connotations of emotions - quite apart from those emotional aspects that are connected with the concept of shonour`. After all, the subject of sadministration and emotions concerns not only individual civil servants but also the question of how emotions develop in social interactions within the administration - in hierarchical relationships or in more horizontal relations. Above all, however, it is also about the emotions of the administrative clientele with which administration is confronted and with which it has to deal.

Thus, various research perspectives for the history of administration are opened up, of which some are only roughly sketched here.

\section{Investigation levels and investigation avenues}

The interrelationship between bureaucracy and emotions can be examined at different levels and with different questions. 


\section{Actors and spaces of emotions}

When it comes to the question of where emotions are to be located, one can initially focus on individual carriers, whereby one can roughly distinguish between administrators and administrative addressees. However, it is also possible to focus on "emotional communities «, ${ }^{4}$ within which the boundary between "administratively internal" and "administratively external« can sometimes not be determined so precisely. Such communities can of course be located in organizational contexts, i.e. as a whole or subset of bureaucracy - which does not mean, however, that such communities stop at the organizational borders. For example, in sectors where "conversation circles « ${ }^{5}$ of administrative and non-administrative actors with common normative ideas have formed, they may also extend to the administrative environment. And finally, communities outside the bureaucracy can also constitute themselves as emotional communities when they generate certain values in confrontation with the administration - the often emotionally highly charged scene of citizens' initiatives is an example of this.

Finally, the practical forms of bureaucratic and legal procedures with their implications for emotional work (»affective labor $«,{ }^{6}$ »emotion work «) $)^{7}$ must be considered, because expectations are inscribed here for a specific handling of one's own emotions and the emotions of sclients`. On the basis of the available source material, emotions can also be assigned to a certain carrier, but these usually only become visible when the results of the individual emotional work do not meet the institutional expectations.

\section{Emotions as (administrative) practice and the construction of emotions}

Emotions can be seen not only as something one has but also as something one does. In this perspective, practical action generates not only emotions but emotions themselves are practices as a way of dealing with the world. ${ }^{8}$ This approach can also be made fruitful for administrative historical investigations. The extent to which emotions enter a habitus (which also determines which emotions are legitimate and which are not) plays a role here; it can be worked out to what extent emotions (perhaps implicitly) are part of strategies for action.

This is connected with the problem of the construction of emotions, and it concerns the development of a certain vocabulary, which first defines what is to be regarded as emotional at all, and determines which manifestations and effects are associated with which emotions. ${ }^{9}$ However, this is also connected with the change in the evaluation of emotions. ${ }^{10}$ This also meant that, despite an invariance of basic psychological dispositions, the linguistic preparation and communication about emotions change - which can manifest itself, on the one hand, in changed administrative guidelines and, on the other hand, in changed expectations of the administrative environment, potentially leading to conflict.

\section{Regulation of emotions}

Finally, from an administrative historical perspective, the question of the regulation of emotions arises. On one hand, a regulatory framework can result from overarching, dominant "emotional regimes« (William Reddy) with a general claim to validity. ${ }^{11}$ However, such an approach could prove to be too coarse on many issues. Rather, a more in-depth analysis of the problem seems possible if one asks specifically how and with what objective which regulatory authorities influence which addressees of regulation. A rough distinction must then be made between the regulation of the emotions of administrative staff and of those addressed by administrative acts. In both cases, regulation is not just one way. Depending on how the effect of the expression of emotions is assessed, regulation can aim at either the suppression and pathologization of emotions or the utilization and even mobilization of emotions.

Finally, one can even think of a normative incorporation of emotions into administrative programmes and thus ultimately of their objectification, so that the social welfare of the modern state can to a large extent be regarded as a rationalizing realization of scompassion « - just as the administrative action of totalitarian states against certain groups can be interpreted as an institutionalized form of legitimized shater. 
The regulation of emotions, however, refers not only to external regulation but also to self-regulation. This includes the self-conditioning of public administrators in their efforts to fulfil their tasks and, at the same time, their understanding of status. Implied here is a selfdiscipline aimed at not allowing inappropriate emotions to flow into the decision-making process as well as a balanced management that allows certain emotions to be taken into account. ${ }^{12}$ Self-regulation of emotions, however, not only means the confrontation between one's own emotional sensitivities and emotion-related norms, but it can also manifest itself in subjective efforts, "to mediate between emotional standards and emotional experience ${ }^{13}{ }^{13}$

It can therefore be said that emotions are not only the object of regulation but also have regulatory potential. This draws attention to emotions as a normative resource. This concerns very specific emotions as well as more complex emotional concepts such as honour, trust and loyalty. In addition to law, technical standards, economic guidelines and other normativities, emotions are thus part of a multinormative regulatory basis for administrative action.

\section{Disciplinary approaches}

These different perspectives on bureaucracy and emotions come into their own in different ways - also depending on which different disciplinary approaches come into play. The history of administration is not a homogenous discipline with a uniform canon of methods and concepts but a very open field of research. Of course, administrative history is a part of history, and therefore, the addressee of the approaches developed there. However, it also has a close connection to administrative sociology and is therefore open to sociological concepts. Finally, it should be borne in mind that administration is to a high degree a legally shaped complex of action and organization; administrative science is to a large extent also conducted by jurists. Therefore, research concepts developed in law are also of importance.

In all three disciplines mentioned, independent research directions have emerged on the topic of remotions«, which usually operate under the following labels: "History of Emotions", "Sociology of the Emotions" and "Law and Emotions". The following remarks give a brief introduction to these research directions. It is hoped that these different disciplinary approaches outlined in the following, whose stylistic variations reflect the diverse disciplinary and linguistic backgrounds of their respective authors, can offer fruitful questions for administrative history.

\section{History of emotions}

With two handbooks published in recent years, the history of emotions seems to have become an established sub-discipline of academic history. ${ }^{14}$ When interest in this field of study began, there might have been some debate about the added value of the emotion perspective in history. As a consequence, many of the frontiers of this field had to combat criticism about their theoretical assumptions. However, it now seems that remotion history is no longer a historical approach that stands in need of justification. Yet, as one of the front-runners in emotion history, Rob Boddice recently warned that the common acceptance of history of emotions as a legitimate field of historical inquiry has a danger, namely, that a "lack of theoretical sophistication « can be on the lure. ${ }^{15}$ Despite this warning, however, one can safely argue that in the last couple of years, historians of emotions have proven to be able to challenge many narratives of modernization and that these studies could provide new perspectives on historical developments in politics, science and economy. This introduction is meant to illustrate what the historian of emotion does, how the discipline has evolved in recent years and how its mode of analysis can challenge the existing literature on the history of bureaucracy and enlarge our understanding of its functioning.

One of the things that drives the work of historians of emotions is the need to articulate the implicit and not always clearly elaborated understanding of emotions in which traditional historiography is often grounded. Many eminent scholars have deployed common-day, mundane understanding of emotional experience and the way people in general act on their emotions, without reflecting on the nature and workings of these feelings. The crucial role empathy played in history, to mention 
one example, however, is something historians of emotions during the last decades have reflected on more fundamentally. As a result, the historical significance of the fact that people started empathizing with different groups of people is now a crucial aspect to the history of humanitarianism and human rights. ${ }^{16}$

As a matter of fact, it should not come as a surprise that historians invest their energy in analysing the role emotions played in history. History is, as the German historicist tradition at least asserts, the science of understanding (Verstehen), and the historian analyses the way historical agents make sense of their world bound by their "horizon of expectations «. ${ }^{17}$ With the two categories of "experience" and "expectation ", as Koselleck advocated, historians therefore have a toolbox at their disposal to analyse the historical nature of political and social concepts. ${ }^{18}$ While the fact that the expectations of historical agents are necessarily emotionally charged - in the sense that they reflect the values people adhere to and to which they are attached - might represent a mundane insight, it does not follow that it is prominently discussed in traditional history writing. ${ }^{19}$

For that matter, an important endeavour for historians of emotions is to highlight the implicit understanding of emotions that are present in classical historical narratives. However, the historian of emotions is often interested in taking this a step further. What they rather pursue is to find the norms and expectations that dictated emotional behaviour itself and to demonstrate that they indeed are also inherently historical. In other words, the aim is to show how these norms and expectations are ingrained in social formations that emerged in history. What prominent historians of emotions have therefore found out is that that various communities have in different ways formulated norms for emotional behaviour, which determined the expectations of members of these communities about what to feel and how to react remotionally،. To see these emotional communities as historical singularities is what the American historian of Medieval Europe Barbara Rosenwein formulated as the most important task of the history of emotions. ${ }^{20}$

The kind of community one can think of varies from case to case. It can be the national community ${ }^{21}$, the scientific community ${ }^{22}$ or any other form of community bound by standards and expectations of emotional behaviour. Yet, as with culture in general, these standards are inherently challenged and stand in constant need of reaffirmation. This emphasis on social norms, moreover, has led other prominent scholars in the field to warn against the pitfall of too much sconstructionism ' and too many studies of the ways people whose emotional experience was marginalized by the ruling emotional regime searched for alternative spaces where they could express their feelings. To give voice to these so-called "emotional refuges «, as William Reddy termed them, has together with the analysis of norms and expectations become a prominent endeavour for most historians of emotions. ${ }^{23}$ These two facts can be summed up in a phrase that Ute Frevert has repeated on several occasions: "emotions both have a history and they make history «. ${ }^{24}$

The thing, however, that has gotten the historical study of emotions particularly on a fast track is the intensive engagement of scholars with the role the body plays in emotional experience and expression. The ways in which emotions are enacted and how these were formed and embodied in the process of history are something traditional historians writing on the topic of emotions were less inclined to include. In modern historical work, however, this has become the kernel of most emotion research. To mention an example, the experience of religious conversion is something bodily enacted, happening in a highly ritualized manner that historical communities have formulated and altered over time, depending on their religious doctrines and ideas about the body. Nonetheless, the way these feelings were embodied can also be the source of deep conflict in certain religious communities when other members of the same faith rather adhere to a restrained and inner experience of religion. ${ }^{25}$ Crucially, therefore, historians have come to see how these embodiments often interact with political and gendered ideologies of the body. ${ }^{26}$ As a result, it is now common sense for historians of emotions to think of them not as an entirely cognitive process but as something that is always embodied; something people not just passively experience but that they actively do. In this sense, Bourdieu's notion of practice has shown to be helpful in understanding this praxeological nature of emotions. ${ }^{27}$ 
Even though histories of emotions seem to cover all spheres of society, there is nonetheless a certain community-bias in the current research. Studies deal with, for instance, the role of emotions in elite circles when they engage in duelling sentiments of solidarity in modern protest movements or the feelings of intimacy that people in oppressed circumstances express; nevertheless, they all start from the assumption that communities are based on emotional ties and thus that emotions are the sine qua non of human communities. ${ }^{28}$ Without fundamentally opposing this idea, it is interesting to note that the roles of emotional experience and emotional norms have received far less attention in the context of modern institutions (except in sociological studies). The question of how within certain institutionalized spaces emotions are expected, enforced and streamlined, however, can very well contribute to the emerging new interest in cultural approaches to the system of bureaucracy. ${ }^{29}$

As a matter of fact, there seems to be a growing interest nowadays in the study of bureaucratic practices from a cultural perspective, which probably started with Michael Lipsky’s seminal work on »Streetlevel bureaucracy «. ${ }^{30}$ In recent years, scholars like Paul du Gay and Vincent Dubois' in their books "In Praise of Bureaucracy" and "The Bureaucrat and the Poor", respectively, have engaged with this topic. However, despite the very interesting thesis of these works, their studies are made rather from an organizational science or sociological/anthropological perspective, and they often neglect a historical perspective on the development of bureaucratic practices. What the history of emotions perspective has to offer is a challenge to those traditional narratives that start with the popular criticism of bureaucracy as a formalized and "cold" form of societal governance (something David Graeber has both recently and vocally expressed in "The Utopia of Rules «). ${ }^{31}$ This image of bureaucratic government, as »cold « and rational, is of course deeply ingrained and goes back to Max Weber's famous description of bureaucracy as a system "without anger and fondness « (sine ira et studio). This dispassionate functioning of modern bureaucracy is, according to Weber, one of the sources of its success because it results in predictable outcomes and procedures. In fact, he juxtaposed bureaucracy and the rational government it embodies in everyday conduct explicitly from charismatic forms of authority - the kind of authority that is most clearly based on the emotional powers of the ruler. ${ }^{32}$ Yet as studies in the history of emotions and science have showed, notions that are closely associated with dispassionateness, such as objectivity, can just as well be viewed as inherently political notions, reflecting the moral values of the practitioners and their emotional attachments to them. ${ }^{33}$

This challenge to a dominant narrative invites a new way of looking at the role of emotions in forms of bureaucratic government. Rather than thinking of emotional experience and expression as a failure of bureaucratic government - as an error in the system - it invites scholars to look at the way affectionate attachments to this form of government were formed in the process. In other words, such a study aims to give a face to the sfaceless bureaucrat . This approach assumes that in the interactions that occur between bureaucrats and clients, there is in fact a constant ongoing negotiation on the permissibility of emotional experience and expression. Many of the studies in this volume show this. Moreover, changes that occur in the moral values that guide bureaucratic practices can also deeply affect the bureaucrats who were formed under the older emotional regime and have to cope with new emotional norms, as their entire emotional economy is ruptured. To give place to these changing norms, it can therefore be fruitful to see the srational form of government as more than just a political ideal but also as an emotional style that is both embodied and always inherently contested.

\section{The sociology of the emotions and administrative practice}

The sociology of emotions covers a broad variety of schools of thought: evolutionary, symbolic interactionist, symbolic interactionist with psychoanalytic elements, interaction ritual, power and status, stratification and exchange. While the topic appears at times in the works of those considered classical sociologists (i.e. Marx's early concern with alienation and "species being «, 34 Simmel's work on estrangement and how conflict 
mobilization involves emotional arousal, ${ }^{35}$ Weber's focus on affect as a type of action and the effects of rationalization ${ }^{36}$ and Durkheim's conceptualization of the origins of religion in ecstatic "effervescence «), ${ }^{37}$ the subfield itself is only about 45 years old, ${ }^{38}$ having been established as a section of the American Sociological Association in 1986.

According to Kathryn J. Lively, "since its inception some four decades ago, the sociology of emotion has been relatively long on theory and short on method, with the majority of scholarship relying on case studies, self-reports, and data gleaned from college students in experimental settings «. ${ }^{39}$ The field may broadly be divided into macro and micro approaches. ${ }^{40}$ As an example of the former, Theodore Kemper's work involves developing a "systematic formulation" in order to "predict with some confidence which emotions are likely to emerge in specified conditions «. ${ }^{41}$ Based on his delineation of an individual's social relations on a grid of power and status, an individual's emotions are a fairly straightforward matter to specify. ${ }^{42}$ An exemplar of the micro approach is Arlie Russel Hochschild's model of emotion management. ${ }^{43}$ Hochschild proposes that individuals attune themselves, through "surface acting " and »deep acting ", to the rules and ideologies of private and public life. In the former, one changes the surface appearance of an emotion without changing the emotion. Hochschild protests the commodification of deep acting, in which one changes his or her inner feeling in order to change his or her emotional expression. ${ }^{44}$ For while emotional work is an everyday phenomenon, ${ }^{45}$ emotional labour, which is compelled by an employer, can bring about emotive dissonance, ${ }^{46}$ which Hochschild argues has the frightening consequence of alienating service workers from their own feelings.

Although Hochschild, with her use of survey data ${ }^{47}$ and interview data, ${ }^{48}$ does not extensively draw on first-hand participant observation, she has provided a theoretical resource for numerous qualitative sociologists who do. ${ }^{49}$ Van Maanen and Kunda, for instance, apply Hochschild's insights to ethnographic studies of the corporate culture of Disneyland and a hightech firm, showing the great lengths to which businesses will go to insure that workers adopt the proper emotional tone with each other and with customers. ${ }^{50}$ Similarly, Leidner shows the extent of the efforts of McDonald's and Combined Insurance salesmen to standardize and routinize workers' emotional tones. ${ }^{51}$

In addition to emotion management, the sociology of emotions holds many promises and opportunities to broaden our understanding of administrative history. A good starting point is the work of Lipsky, who provides an inside view of the common dilemmas faced by streetlevel bureaucrats, an umbrella term that includes teachers, police, welfare workers and other state agents who deal directly with the public. ${ }^{52}$ Lipsky reveals three sources of pressures for such workers. ${ }^{53}$ The first is the conflict between meeting the needs of their clients while operating in an efficient and effective manner. The second problem is an ongoing lack of resources, as client needs tend to increase in proportion to agents' increasing resources. ${ }^{54}$ Third, street-level bureaucrats are frequently alienated from their work, for while they may have entered their profession with altruistic motives, they must also efficiently judge and control clients in the effort to meet the needs of the maximum number of them. By probing such contradictory strains within street-level bureaucracies, Lipsky represents a sympathetic voice for such workers, shedding light on the reasons such work is often frustrating for clients, workers and advocates and showing why the achievement of policy goals is problematic at best. ${ }^{55}$

Another contributor to this emotional "inside" view of how decisions are implemented is provided by Emerson. ${ }^{56}$ While "context " for Lipsky refers to the contradictory expectations under which street-level bureaucrats work, for Emerson, it refers to "processes whereby particular traits are invoked or made relevant to particular decisions «. ${ }^{57}$ Among such invoked traits are the implications of other cases being processed for judging a current case, ${ }^{58}$ the "real reasons" that agents infer as underlying the "official reasons « behind referrals ${ }^{59}$ and the source of complaints and the potential outcomes of complaints as determined by deputy district attorneys when deciding whether to file police officer's complaints. ${ }^{60}$ Common to each study is an emphasis that such contextual traits are not simply experienced by members ${ }^{61}$ and are not factual descriptions of their procedures ${ }^{62}$ but are rather invoked by agents to "establish the orderly, practically rational character of their decisions ${ }^{63}$ 
Emotions are especially prominent when such procedures are breeched. The sociology of troubles focuses on how troubles are »identified, reacted to, and elaborated «. Emerson and Messinger's piece provides a wholistic view of trouble from the ground up, proposing that the recognition of "deviance" often begins with "a vague sense of >something wrong « ${ }^{64}$ rather than being constituted merely through institutional labelling processes. ${ }^{65}$ Often such a vague sense coincides with the weighing of remedies, some of which may work and others may eventually fail, potentially leading to a cycle of trouble, remedy, failure and more trouble. The authors note, this "effort to find and implement a remedy is critical to the processes of organizing, identifying, and consolidating the trouble ${ }^{66}$ Integral in this response is the formulation of the trouble as intrapersonal or relational, not to mention the intervention of a third party, which "reconstitutes the trouble as a distinctly public phenomenon « and may »fundamentally shape what the trouble will become ${ }^{67}$ Thus, as the trouble becomes a public phenomenon, it is "produced procedurally, by the responses of troubleshooters, and not simply by their definitions of the trouble «. ${ }^{68}$

The occasion of sbad news ‘ is also intuitively striking as an opportunity for the expression of emotion. Unlike studies of trouble, which typically concern efforts to manage and remedy the phenomenon, but have difficulty gaining access to the phenomenon itself, studies of bad news have access to the phenomenal present of the emotion-laden moment in which bad news is delivered. McClenahen and Lofland depict deputy U.S. marshals' tactics of delivering bad news (which must be done several times a day) as involving a "nice guy impersonality«, through which they both "scale down the badness" of their report and "distance" themselves from recipients' responses. Specifically, they describe a number of "shoring " practices to bolster the recipient after the news is delivered, providing advice about prison such as, "it's not as bad as you think" or that "it could have been worse ${ }^{69}$ They also work to mitigate the demeaning aspects of confining mechanisms such as handcuffs by blaming their use on rules from superiors, and they employ a standard set of quips and jokes when performing routinized duties, like fingerprinting or taking mug shots. The authors explain such tactics as a practical response to the desire to avoid ssticky< emotional situations, since the bad news bearer often must remain with the recipient after the news is delivered, to transport them to jail and perform various routine procedures. The authors are careful to note, however, that this is only one strategy for the delivery of bad news and that strategies may change in different organizational contexts. ${ }^{70}$

While McClenahen and Lofland ground their analysis in the organizational context of talk, Maynard grounds his studies of physicians' delivery of diagnostic news (at clinics specializing in developmental disabilities) in the interactional structures of talk and elucidates a number of novel conversational structures en route. ${ }^{71}$ Primary among these is the "perspective-display series «, in which news deliverers ask news recipients for their view on the matter prior to informing them. ${ }^{72}$ Such a form of delivery "maximizes the possibility for presenting clinical findings as in agreement with recipients' views and minimizes the potential for disagreement $« .{ }^{73}$ These perspective-display invitations come in two forms, marked and unmarked. The former initiates reference to a problem and "can be considered as suggestions or proposals which require acceptance «, ${ }^{74}$ while the later, "which ask in more generalized terms about the child, are not presumptive in this way «. ${ }^{75}$ While such structures of news delivery "demonstrate participants' sensitivity to the interactional context of news delivery and receipt", they also "display accountable aspects of the institutional order " by reproducing features embedded in prior encounters with the clinic and foreshadow future encounters between professionals and the family. ${ }^{76}$ Thus, Maynard not only describes the details of the structure of talk in an institution but also shows that talk reflexively invokes and orders the context of the setting. Maynard notes in passing how bad news deliverers "have to contend with emotional reactions of recipients « and may even become emotional themselves. ${ }^{77}$

In conclusion, while the study of emotions is a new and exciting topic within sociology, it is also an enigmatic and slippery one. There are a number of reasons for such difficulties. First, emotions are quick. Often they come and go without one realizing it, and when one does stop to realize or analyse it, the emotion is gone (one is then doing an analysis). Second, emotions are embodied phenomena. Unlike discursive practices 
that can be deciphered and analysed in numerous ways, emotions are messy and often difficult to interpret. ${ }^{78}$ Third, emotions have a wholly contextualized meaning. My laughter when I hear a joke a second time is wholly different from when I hear it the first time and I laugh differently whether my boss or a child tells the joke. Fourth, emotions resist rhetoric. As Katz states, "our ways of transforming emotional experience into analytic topics are always somewhat pathetic in that they risk misrepresenting the forces they seek to grasp «. ${ }^{79}$ No matter how flowery or exacting the prose, something will always be lacking when we attempt to translate such a quick, embodied, deeply contextualized phenomena.

\section{Administrative history and "law and emotions"}

One of the more promising scientific approaches for an administrative history focussed on emotions is a research approach that can be summarized under the catchword "law and emotions«. However, it should be mentioned that this is not a coherent theory. Rather, we are dealing with a multitude of approaches that pursue different research directions and are partly based on different theoretical assumptions. In order to clarify this and also to clarify the possible relevance for administrative history, it is important that we first discuss what is to be understood by "law and emotions".

In the United States, the law and emotions approach is the most influential, carries the most intellectual clout and demonstrates the broadest differentiation. There it has established itself as a self-contained legal sub-discipline. It began when feminists and other representatives of critical legal theory addressed emotions in terms of a challenge to traditional legal doctrine. Prior to this, doctrines were very much focussed on rationality, which meant emotions were only permitted to play a secondary role. The early works on law and emotion mainly aimed at the legitimation of an alternative approach. In the 1990s, the focus shifted from legitimacy to the investigation of emotions and their significance in law itself. ${ }^{80}$ Emotions were no longer merely the signature of a critical attitude towards established jurisprudence but instead had become the subject of investigation. ${ }^{81}$ The "normative turn « took place around 2000, and within the context of this turn, the focus shifted "from understanding emotions to working with the law ${ }^{82}$ The emphasis now involved making knowledge of emotions useful for law - both for jurisprudence and for legal practice. This has resulted in a multitude of orientations with diverse target directions and object references. ${ }^{83}$

Research approaches that have developed in Germany are by no means comparable in terms of scale. To a certain extent, they have their own character, which is clearly connected with their embeddedness within a certain tradition of legal thinking. This is expressed in a particular terminology, for example, "sense of justice» (Rechtsgefühl). "Sense of justice« was already a guiding concept in 19th-century legal literature, ${ }^{84}$ and it has also graced the title of works that appeared in the 20th and 21st centuries. ${ }^{85}$ The conceptual content of "sense of justice « certainly demonstrated a particular semantic variety: 1) belief in the legitimacy of the existing legal system; 2) knowledge of what is law in a particular legal system; or 3) a feeling for what should be right. ${ }^{86}$ This already signals an initial difference to the (predominantly) American research approach of "law and emotions«: The topos "sense of justice" is more narrowly focussed. While the discussion on "law and emotions" is about the role of emotions in legal decision-making processes and legal considerations, the debate on the "sense of justice" revolves around emotions that directly define law ${ }^{87}$ - although there are also approaches in the German discussion that take up impulses from the "law and emotions " debate and thus pursue a broader investigative avenue. ${ }^{88}$ And there is another important difference. In Germany, the discussion concerning legal feelings plays an extremely marginal role; it is almost non-existent in academic teaching. It has never gained a foothold in jurisprudence because of the overpowering influence of legal doctrine; even in legal sociology, which would certainly be more open to such influences, it continues to be considered as a foreign element. ${ }^{89}$ Moreover - and this constitutes another difference to the "law and emotions « approach - it tends to manifest itself in theoretical discussions rather than in empirical studies (of which there are few). 
However, what could the results of a jurisprudential examination of emotions yield for administrative history? In order to work this out, it is helpful to first discuss three possible objections to the integration of these approaches into an administrative-historical perspective.

The first objection is that the legal debate relates largely ${ }^{90}$ to the present context, and therefore, its findings are not historically applicable. As far as this argument refers to the basic structures of law, a distinction must be drawn between spre-modern ‘ and smodern ‘ law (even if this distinction is somewhat blurry, which we will not go into here). In principle, it can be said that pre-modern law has a fundamentally different mode of dealing with emotions than that of modern law. Law in the Middle Ages and the early modern period objectified emotions and made them part of legal programmes of action. ${ }^{91}$ Modern law since the Age of Enlightenment, on the other hand, demonstrated abstinence from emotions and >dethematized ‘ them. Thus, as far as the historical development of modernity is concerned, i.e. the last 200 years, the basic statements of the current discussion can - with all due caution - also be made applicable.

The second objection concerns a fundamental methodological problem. Given that legal discussions always have a normative perspective, the main question comes down to what is right. From a historical perspective, however, the primary question is about what is true. ${ }^{92}$ Yet, this objection can be answered: First, categories developed with a normative intent can also be used for empirical-analytical purposes, provided they are sufficiently abstract. Second, the entire discussion concerning "law and emotions" cannot be understood as a purely normative discussion because, to a large extent, this discussion is also about empirical assumptions. The same applies to the research on the "sense of justice».

Finally, the third objection is subject related: The subject of the legal debate is law, i.e. legal norms, legal procedures and legal discourses. From the perspective of administrative history, however, administrative standards of action, administrative procedures and administrative scientific, especially administrativehistorical discourses, play a role. The objection therefore relates to the incongruence of subject areas. This objection is important because it refers to the different normative character of administrative cultures. On the one end of the scale, there is a pronounced legalist administrative culture in which administration is understood merely as the enforcement of law. From a contemporary perspective, i.e. from a more poignant point of view, this is the German administration. At the other end of the scale is an administrative model in which administration is viewed as an instrument for enforcing political decisions. Put simply, the usability of the findings from the debate on "law and emotions", and also on the "sense of law « depends on the respective legalistic character of the administration: The more legalistic an administration is, the easier it is to transfer knowledge or questions of a jurisprudential treatment of emotions. However, there is another limitation to be taken into account here: The research on "law and emotions " mainly relates to the legal system of the United States, which differs fundamentally from other legal systems, especially the continental European legal systems. In view of these differences, the issue as to which findings or questions are transferable and which are not needs to be clarified. Finally, a third restriction must be pointed out in this context. Much of the work in the context of "law and emotions « focuses on a specific area of law: criminal law. This area of law in particular has a special affinity to emotions. ${ }^{93}$ From an administrative historical perspective, however, criminal law does not play a significant role. Since the systematic separation of justice and administration at the beginning of the 19th century, administrative authorities have hardly been concerned with the application of criminal law or criminal procedure standards - the police authorities representing an important exception. In this respect, too, the limited transferability of findings from research on law and emotion should be pointed out.

After discussing the possibilities and limits of making the legal study of emotions usable, we want to point out certain possible levels of reception. It is less a question of adopting certain results than of focussing on questions that have been developed by law and emotion research.

In general, it should be emphasized that the emotions that play a role in the legal debate are also relevant from an administrative historical perspective. This concerns negatively connotated emotions such as shame, disgust, fear and anger, as well as positively 
connotated emotions such as loyalty, gratitude, generosity, elevation and awe. ${ }^{94}$ A similar situation can also be noted with regard to the sources. Rosenwein ${ }^{95}$ has pointed out that there are both sources in which emotions are clearly expressed and those that deal with emotionally connoted facts but do not express this emotional dimension. Both legal ${ }^{96}$ and administrative sources belong predominantly to the second group of sources.

If one now comes to the individual investigation avenues or fields of investigation, one possibility is to divide this according to persons, procedures and organizations. ${ }^{97}$ With regard to the first, the legal-actor approach has emerged in law and emotion research, and it examines how emotions influence the gathering of information and decision-making process of persons making legal decisions, which explicitly include administrative officials. ${ }^{98}$ However, two important differences between judicial and administrative officials should be highlighted. First, administrative officials are much more connected with the administrative environment than members of the judiciary are with the judicial environment. ${ }^{99}$ The reasons for this are 1) the greater specialization and 2) the need to cooperate with the administrative clientele in order to achieve appropriate results. As such, a closer proximity to and the effects of group dynamics that develop in the administrative environment must be taken into account in terms of emotional dynamics. ${ }^{100}$ Second, it should be noted that administration is more closely interwoven with politics than the judiciary. That this resulted in fundamental differences was already registered in the 19 th century and led to different, emotionally contoured typifications of judges and administrative officials. ${ }^{101}$

As far as the procedural level is concerned, a distinction must first be made between types of procedures in terms of types of decision-making. Luhmann, in particular, has made the distinction between conditional and final programming prominent. ${ }^{102}$ Conditional programming means that decisions are made according to an sif-then scheme, i.e. that the existence of certain conditions results in a decision with a fixed content. The situation is different for procedures that follow the principle of final programming. Final programming means that the decision is not fixed; instead, only general objectives exist. While conditional programming is typical of judicial procedures, both conditional and final programming can be found in administration. This also has consequences for the role of emotions. Although it is also recognized that decisionmaking involving conditional programming is often intuitive, ${ }^{103}$ final programming is much more open in this respect, as the decision is not clearly determined by law.

This is related to another factor: Procedures characterized by final programming are often characterized by a complex participant structure, especially when they are planning procedures. Such procedures are characterized not only by the processing of complex information situations and the interrelation of a multitude of divergent calculations of interests but also by the balancing of diverse moods. This is particularly important in the case of administrative procedures involving public participation, ${ }^{104}$ in which the parties also want to strengthen their position by mobilizing emotions.

Finally, we should draw attention to a constant within the discussion on judicial procedures, which is also of emotional historical relevance. It can be summarized under the heading: "Judging or conciliation « (Richten oder Schlichten). ${ }^{105}$ 'Judging ( means the traditional procedural mode of judicial decision-making, whereas sconciliation means a procedural mode in which not only a legal subsumption takes place but also a decision is to be issued - one more strongly anchored in the life world of the parties concerned. This is not just a matter of a process-technological alternative. Rather, this is a matter of fundamental decisions: Should the "cold legal rationality" decide in a legal dispute, or should an "Equitas", which also takes the emotions of those affected seriously, ${ }^{106}$ guide the decision. Ultimately, this conflict has also affected the history of administration. This is generally expressed in the discussion about the "popularity" (Volkstümlichkeit) of the administration; ${ }^{107}$ in particular, from a procedural point of view, this manifests itself in the today's debate about the introduction of mediation in the administrative procedure. ${ }^{108}$

Organizational aspects have an important significance in law and emotion research. There, of course, the jury plays an important role as a special organizational variant of judicial decision-making. 
An organizational form comparable to that of the jury can hardly be found in administration. However, the research on the jury draws attention to two aspects that are also of importance in the history of administration: 1) How do collectives decide? What emotional dynamics can be observed in processes of collective decisionmaking? Can the discussion in collectives also reduce negative moods in administrative colleges, as is assumed in jury research? ${ }^{109}$ This aspect of the role of collectives is particularly interesting from an administrative historical perspective, because in Germany in the 19th century, the collegial principle was much more important than it is today, i.e. administrative decisions were made by collegial bodies rather than by monocratic heads of authorities. ${ }^{110}$ 2) How do laypersons - who have a different sense of justice than professional lawyers ${ }^{111}$ - decide? Which moods are able to influence their decisions? However, from an administrative-historical perspective, the aspect of lay participation is to be assessed differently than in the area of justice. In the field of jurisdiction, we are dealing with a dichotomy of lawyers and non-lawyers. This dichotomy could only be transferred to administrations if the professional administrators were lawyers. However, this is only partially the case, even in administrations such as the German one, with its (already significantly weakened) "monopoly of lawyers" (Juristenmonopol). Here, it would be better to draw the line between professional civil servants, with their official rationality acquired through special training and routine, on the one hand, and volunteer citizens who, for example, sit on administrative bodies as assessors, on the other hand.

Another aspect highlighted by law and emotion research is the relationship between emotions and institutional structures. This concerns, for example, the question of which incentive systems linked to certain emotional dispositions have been created and implemented in organizations. ${ }^{112}$ However, this is not only about conscious organizational decisions. In certain organizational configurations, a certain esprit de corps is also formed through tradition, which in turn is connected with certain basic emotional moods: Organizations can also produce emotional collectives. 
1 Benno Gammerl / Bettina Hitzer: „Wohin mit den Gefühlen? Vergangenheit und Zukunft des Emotional Turn in den Geschichtswissenschaften«, in: Berliner Debatte 24/3 (2013), pp. 31-40. An overview of the state of research with a comprehensive bibliography can be found at Bettina Hitzer: »Emotionsgeschichte - Ein Anfang mit Folgen«, in: H-Soz-Kult, online: www.hsozkult.de/ literaturereview/id/forschungsberichte-1221 (23. 11. 2011).

2 Hilde Haider: "Emotionen als Steuerungselement menschlichen Handelns«, in: Birgit Aschmann (ed.): Gefühl und Kalkül. Der Einfluss von Emotionen auf die Politik des 19. und 20. Jahrhunderts, Stuttgart 2005, pp. 33-47, at pp. 37-44.

3 Agnes Heller: Theorie der Gefühle, Hamburg 1980, p. 131.

4 Barbara H. Rosenwein: "Problems and Methods in the History of Emotions", in: Passions in Context 1 (2010), online: https://www. passionsincontext.de/uploads/media/01_Rosenwein.pdf (1. 8. 2018).

5 Michael Hutter: Die Produktion von Recht. Eine selbstreferentielle Theorie der Wirtschaft, angewandt auf den Fall des Arzneimittelpatentrechts, Tübingen 1989, pp. 90-103.

6 Michael Hardt: »Affective Labor«, in: Boundary 26/2 (1999), pp. 89100.

7 Arlie R. Hochschild: „Emotion Work, Feeling Rules, and Social Structure«, in: The American Journal of Sociology 85/3 (1979), pp. 551-575.

8 Monique Scheer: "Are Emotions a Kind of Practice (and Is That What Makes Them Have a History)? A Bourdieuian Approach to Understanding Emotion«, in: History and Theory 51 (2012), pp. 193220.

9 Daniela Saxer: »Mit Gefühl handeln. Ansätze der Emotionsgeschichte«, in: Traverse 14 (2007), pp. 15-29, at pp. 16-17.

10 Ute Frevert: »Historicizing Emotions«, in: Emotion Researcher: ISRE's Sourcebook for Research on Emotion and Affect, online: http:// emotionresearcher.com/historicizing-emotions/ (14. 3. 2018).

11 See below for more details.

12 Terry A. Maroney: „Emotional Regulation and Judicial Behavior«, in: California Law Review 99 (2011), pp. 1485-1556.

13 Peter N. Stearns / Carol Z. Stearns: „Emotionology: Clarifying the History of Emotions and Emotional Standards«, in: The American Historical Review 90 (1985), pp. 813-836, at p. 825.

14 Jan Plamper: Geschichte und Gefühl. Grundlagen der Emotionsgeschichte, München 2012; Rob Boddice: The History of Emotions, Manchester 2018.

15 Rob Boddice: „The History of Emotions: Past, Present, Future«, in: Historia de las emociones: pasado, presente y futuro 62 (2017), pp. 10-15.

16 Important advocates of this are found in: Thomas W. Lacquer: "Bodies, Details and the Humanitarian Narrative«, in: Lynn Hunt (ed.): The New Cultural History, Berkeley 1989, pp. 176-204; Lynn A. Hunt: Inventing Human Rights. A History, New York 2007; Aleida Assmann / Ines Detmers (eds.): Empathy and Its Limits, Basingstoke 2016.

17 Cf. Wolfgang J. Mommsen: „Wandlungen im Bedeutungsgehalt der Kategorie des /Verstehens «, in: Christian Meier / Jörn Rüsen (eds.): Theorie der Geschichte, München 1988, pp. 200-226.

18 Reinhart Koselleck: Vergangene Zukunft. Zur Semantik geschichtlicher Zeiten, Frankfurt am Main 1979, pp. 349-375.

19 Cf. Martha C. Nussbaum: Upheavals of Thought. The Intelligence of Emotions, Cambridge 2001

20 Barbara H. Rosenwein: "Worrying about Emotions in History«, in: The American Historical Review 107/3 (2002), pp. 821-845; Barbara H. Rosenwein: Generations of Feeling. A History of Emotions, 6001700, Cambridge 2015
21 To mention a few examples: Frank Biess: Republik der Angst. Die andere Geschichte der Bundesrepublik, Berlin 2018; Thomas Dixon: Weeping Britannia. Portrait of a Nation in Tears, Oxford 2015; Ville Kivimäki / Tuomas Tepora: „War of Hearts. Love and Collective Attachment As Integrating Factors in Finland During World War II«, in: Journal of Social History 43/2 (2009), pp. 285-305; Susan J. Matt: Homesickness. An American history, New York 2011; Stephanie Olsen: Juvenile Nation. Youth, Emotions and the Making of the Modern British Citizen, 1880-1914, London 2015; Peter N. Stearns: American Cool. Constructing a Twentieth Century Emotional Style, New York 1994.

22 Examples: Rob Boddice: The Science of Sympathy. Morality, Evolution, and Victorian Civilization, Urbana 2016; Fay Bound Alberti (ed.): Medicine, Emotion and Disease, 1700-1950, Basingstoke 2006; Paul White: „Darwin's Emotions. The Scientific Self and the Sentiment of Objectivity«, in: Isis 100/4 (2009), pp. 811-826.

23 William M. Reddy: "Against Constructionism. The Historical Ethnography of Emotions", in: Current Anthropology 38/3 (1997), pp. 327-351; William M. Reddy: The Navigation of Feeling. A Framework for the History of Emotions, Cambridge 2001.

24 Ute Frevert: Emotions in History. Lost and Found, Budapest 2011.

25 Pascal Eitler / Bettina Hitzer / Monique Scheer: »Feeling and FaithReligious Emotions in German History“, in: German History 32/3 (2014), pp. 343-352.

26 Hera Cook: »Emotion, Bodies, Sexuality, and Sex Education in Edwardian England«, in: The Historical Journal 55/2 (2012), pp. 475495.

27 Scheer: »Are Emotions a Kind of Practice«, pp. 193-220.

28 Think of examples such as: Ute Frevert: Men of Honour. A Social and Cultural History of the Duel, Cambridge 1995; Joachim C. Häberlen / Jake P. Smith: »Struggling for Feelings. The Politics of Emotions in the Radical New Left in West Germany, c. 1968-84«, in: Contemporary European History 23/4 (2014), pp. 615-637; Will Jackson: »The Private Lives of Empire: Emotion, Intimacy, and Colonial Rule», in: Itinerario 42/1 (2018), pp. 1-15.

29 Studies in the role of space, however, are engaging more directly with this question. Cf. Margrit Pernau: „Space and Emotion. Building to Feel«, in: History Compass 12/7 (2014), pp. 541-549.

30 Michael Lipsky: Street-Level Bureaucracy. Dilemmas of the Individual in Public Service, New York 2010.

31 David Graeber: The Utopia of Rules. On Technology, Stupidity, and the Secret Joys of Bureaucracy, London 2015.

32 Max Weber: Wirtschaft und Gesellschaft, Tübingen 2013.

33 Lorraine Daston / Peter Galison: Objectivity, New York 2007.

34 Karl Marx: Economic and Philosophic Manuscripts of 1844, ed. by Martin Mulligan, Moscow 1959.

35 Georg Simmel: "The Stranger«, in: Donald Levine (ed.): On Individuality and Social Forms, Chicago, IL, 1971, pp. 143-150; Donald Levine: The Metropolis and Mental Life. The Sociology of Georg Simmel, New York 1976.

36 Max Weber: "Political Writings«, ed. by Peter Lassman / Ronald Speirs, Cambridge 1994

37 Emile Durkheim: The Elementary Forms of the Religious Life, London 1912.

38 Jonathan Turner: »The Sociology of Emotions: Basic Arguments", in: Emotion Review 1/4 (2009), pp. 340-354, at p. 340.

39 Kathryn J. Lively: »Comment on >Methodological Innovations From the Sociology of Emotions - Methodological Advances «", in: Emotion Review 7/2 (2015), pp. 181f., at p. 181; s. a. Jan E. Stets / Jonathan H. Turner: Handbook of the Sociology of Emotions 2, New York 2014.

40 Peggy Thoits: "The Sociology of Emotions«, in: Annual Review of Sociology 15 (1989), pp. 317-342. 
41 Theodore K. Kemper: Research Agendas in the Sociology of Emotions, Albany, NY, 1990, pp. 208-237.

42 Kemper: Research Agendas in the Sociology of Emotions, p. 220.

43 Arlie Russell Hochschild: "Emotion Work, Feeling Rules, and Social Structure«, in: American Journal of Sociology 85/3 (1979), pp. 551-575; idem: The Managed Heart. Commercialization of Human Feeling, Berkeley, CA, 1983; idem: »Ideology and Emotion Management. A Perspective and Path for Future Research«, in: Theodore D. Kemper (ed.): Research Agendas in the Sociology of Emotions, Albany, NY, 1990, pp. 117-142; idem: "The Sociology of Emotion As a Way of Seeing", in: Gillian Bendelow / Simon J. Williams (eds.): Emotions in Social Life. Critical Themes and Contemporary Issues, London 1998, pp. 3-15; idem: „Emotional Life on the Market Frontier «, in: Annual Review of Sociology 37 (2011), pp. 21-33.

44 Hochschild: The Managed Heart, p. 38. Hochschild notes that surface acting is akin to the acting technique of the Coquelin school, while she borrows Stanislavski's concept of method acting to depict the skills involved in deep acting.

45 Hochschild: »Emotion Work«; idem: »Ideology and Emotion«. According to Hochschild (especially 1979, 1990), everyday participants in society engage in surface acting and deep acting on a routine basis so that their inner emotional state adheres to, or at least appears to adhere, to the ideological demands of various occasions (such as happiness at weddings and grief at funerals) and gender roles (s. a.: Hochschild: »The Sociology of Emotion«).

46 Hochschild: The Managed Heart, p. 90.

47 Hochschild: „Emotion Work«, p. 561; idem: The Managed Heart, pp. $12 \mathrm{f}$.

48 Hochschild: „Emotion Work«; idem: »The Sociology of Emotion«.

49 Robert Garot: "'You're not a Stone`. Emotional Sensitivity in a Bureaucratic Setting", in: Journal of Contemporary Ethnography 33/6 (2003), pp. 735-766; Robin Leidner: Fast Food, Fast Talk. Service Work and the Routinization of Everyday Life, Berkeley, CA, 1993; Robert I. Sutton: "Maintaining Norms about Expressed Emotions. The Case of Bill Collectors«, in: Administrative Science Quarterly 36 (1991), pp. 245-268; Allen C. Smith / Sherryl Kleinman: "Managing Emotions in Medical School. Students' Contacts with the Living and the Dead", in: Social Psychology Quarterly 52/1 (1989), pp. 56-69; Barbara Stenross / Sherryl Kleinman: „The Highs and Lows of Emotional Labor. Detectives' Encounters with Criminals and Victims«, in: Journal of Contemporary Ethnography 17 (1989), pp. 435-452; John van Maanen / Gideon Kunda: »Real Feelings. Emotional Expression and Organizational Culture«, in: Research in Organizational Behavior 11 (1989), pp. 43-103.

50 Van Maanen / Kunda: »Real Feelings«.

51 Leidner: Fast Food.

52 Lipsky: Street-Level Bureaucracy.

53 Gale Miller: Enforcing the Work Ethic. Rhetoric and Everyday Life in a Work Incentive Program, Albany, NY, 1991.

54 Lipsky: Street-Level Bureaucracy, p. 33.

55 See Robert Garot: "Sprachspiele im Wohnungsamt«, in: Peter Becker (ed.): Sprachvollzug im Amt. Kommunikation und Verwaltung in Europa, Bielefeld 2011, pp. 157-184; idem: „Immigration Law and Discretion in Contemporary Italy", in: David Brotherton / Daniel Stageman / Shirley Leyro (eds.): Outside Justice, New York 2013, pp. 163-177; idem: „The Psycho-Affective Echoes of Colonialism in Fieldwork Relations«, in: Forum Qualitative Social Research 15/1 (2014), online: http://nbn-resolving.de/urn:nbn:de:0114-fqs1401125 (1. 8. 2018).

56 Robert M. Emerson: Judging Delinquents. Context and Process in Juvenile Court, Chicago, IL 1969; idem: »Holistic Effects in Social
Control Decision-Making«, in: Law and Society Review 17 (1983), pp. 425-455; idem: "Case Processing and Interorganizational Knowledge. Detecting the >Real Reasons` for Referrals«, in: Social Problems 38 (1991), pp. 198-212; idem: »Disputes in Public Bureaucracies«, in: Susan S. Silbey / Austin Sarat (eds.): Studies in Law, Politics and Society 12, Part A, Greenwich, CT, 1992, pp. 3-29.

57 Emerson: »Disputes in Public Bureaucracies«, p. 232.

58 Emerson: »Holistic Effects«.

59 Emerson: „Case Processing«.

60 Emerson: »Disputes in Public Bureaucracies«.

61 Emerson: "Case Processing".

62 Emerson: »Holistic Effects«, p. 19.

63 Emerson: »Disputes in Public Bureaucracies«, p. 19.

64 Robert M. Emerson / Sheldon L. Messinger: »The Micro-Politics of Trouble«, in: Social Problems 25/2 (1977), pp. 121-134, at p. 121.

65 i. e. Howard S. Becker: Outsiders. Studies in the Sociology of Deviance, New York 1963.

66 Emerson / Messinger: »The Micro-Politics of Trouble«, p. 122.

67 Emerson / Messinger: »The Micro-Politics of Trouble«, p. 128.

68 Emerson / Messinger: »The Micro-Politics of Trouble«, p. 131.

69 Lachlan McClenahen / John Lofland: »Bearing Bad News. Tactics of the Deputy U.S. Marshal«, in: Sociology of Work and Occupations 3/3 (1976), pp. 251-272.

70 See Garot: »'You're Not a Stone«.

71 Douglas Maynard: "Bearing Bad News in Clinical Settings», in: Brenda J. Dervin / Melvin J Voigt (eds.): Progress in Communication Sciences. Norwood, NJ, 1991, pp. 143-172; idem: "The PerspectiveDisplay Series in the Delivery and Receipt of Diagnostic News«, in: Deidre Boden / Don H. Zimmerman (eds.): Talk and Social Structure, Berkeley 1991, pp. 164-194; idem: „On Clinicians Co-implicating Recipients' Perspective in the Delivery of Diagnostic News , in: Paul Drew / John Heritage (eds.): Talk at Work, London 1992, pp. 331-358.

72 Maynard: „Bearing Bad News«; idem: »On clinicians».

73 See Maynard: "Bearing Bad News«, p. 165; McClenahen / Lofland: "Bearing Bad News«, p. 270, who report a similar phenomenon that they refer to as "presaging" when news deliverers "build up to the news« or even lead the news recipient into "questioning them«.

74 See Maynard: » The Perspective-Display Series«, p. 170.

75 Maynard: »The Perspective-Display Series«, p. 173.

76 Maynard: „The Perspective-Display Series«, pp. $188 \mathrm{f}$.

77 Maynard: »Bearing Bad News«, p. 148.

78 David D. Franks: "Notes on the Bodily Aspect of Emotions. A Controversial Issue in Symbolic Interaction «, in: Studies in Symbolic Interaction 8 (1987), pp. 219-233.

79 Jack Katz: »Metamorphoses in Everyday Life. Slips, Jokes, and other Slight Gestures toward the Understanding of Emotions in 20th Century Social Psychology«, Unpublished paper, Los Angeles, CA, 1995.

80 Kathryn Abrams / Hila Keren: "Who's Afraid of Law and the Emotions«, in: Minnesota Law Review 94 (2009-2010), pp. 19972074, at pp. 2003-2011.

81 Above all: Susan A. Bandes (ed.): The Passions of Law, New York 2000.

82 Abrams / Keren: „Who's Afraid«, p. 2011.

83 Overview in: Abrams / Keren: »Who's Afraid«, pp. 2034-2073; Terry A. Maroney: "Law and Emotion. A Proposed Taxonomy of an Emerging Field«, in: Law and Human Behavior 30 (2006), pp. 119-142, at pp. 126-133; Susan A. Bandes / Jeremy A. Blumenthal: „Emotion and the Law«, in: Annual Review of Law and Social Sciences 8 (2012), pp. 161-181, at pp. 172-174. 
84 See in particular Gustav Rümelin: „Über das Rechtsgefühl (1871)«, in: Gustav Rümelin: Reden und Aufsätze, Tübingen 1875, pp. 62-87.

85 Walter Heinemann: "Zur Phänomenologie des Rechtsgefühls», in: Alexander Hollerbach / Werner Maihofer / Thomas Würtenberger (eds.): Mensch und Recht. Festschrift für Erik Wolf zum 70. Geburtstag, Frankfurt am Main 1972, pp. 57-79; Ernst Joachim Lampe: Das sogenannte Rechtsgefühl, Opladen 1985; Klaus Obermayer: »Über das Rechtsgefühl«, in: Juristenzeitung 1986, pp. 1-5; Erhard Blankenburg: „Empirisch meßbare Dimensionen von Rechtsgefühl, Rechtsbewußtsein und Vertrauen in Recht«, in: Hagen Hof / Hans Kummer / Peter Weingart (eds.): Recht und Verhalten - Verhaltensgrundlage des Rechts - zum Beispiel "Vertrauen«, Baden-Baden 1994, pp. 83-110; Reiner Schützeichel: "Soziologie des Rechtsgefühls«, in: Hilge Landweer / Dirk Koppelberg (eds.), Recht und Emotion 1, Freiburg / München 2016, pp. 65-99; Sigrid G. Köhler et al.: »Recht fühlen. Zur Persistenz einer diskursiven / medialen Übersetzungsfigur «, in: Sigrid G. Köhler et al. (eds.): Recht fühlen, Paderborn 2017, pp. 9-18.

86 Schützeichel: "Soziologie des Rechtsgefühls«, pp. 72-74.

87 Köhler et al.: Recht fühlen, pp. $9 f$.

88 Dagmar Ellerbrock / Sylvia Kesper-Biermann: "Between Passion and Senses? Emotional Dimensions of Legal Cultures in Historical Perspective«, in: Dagmar Ellerbrock / Sylvia Kesper-Biermann (eds.): Between Passion and Senses? Perspectives on Emotions and Laws., Bielefeld 2015, pp. 1-15; for similar results, refer Hilge Landweer / Dirk Koppelberg: „Der verkannte Zusammenhang von Recht und Emotion«, in: Hilge Landweer / Dirk Koppelberg (eds.): Recht und Emotion 1, Freiburg / München 2016, pp. 13-47, at p. 15.

89 Schützeichel: „Soziologie des Rechtsgefühls«, p. 67.

90 One important exception: Ellerbrock / Kesper-Biermann: »Between Passion and Senses?«; see also the projects of the research area "Law and Emotions" at the Max-Planck-Institute for Human Development, Berlin, online: https://www.mpib-berlin.mpg.de/ en/research/history-of-emotions/projects/law-and-emotions (1. 8. 2018).

91 António Manuel Hespanha: „Early Modern Law and the Anthropological Imagination of Old European Legal Culture«, in: John A Marino (ed.): Early Modern History and the Social Sciences. Testing the Limits of Braudel's Mediterranean, Kirksville, MO, 2002, pp. 191-204, at pp. 196-203.

92 Hespanha: »Early Modern Law«, pp. 196-203.

93 Ellerbrock / Kesper-Biermann: »Between Passion and Senses?«, p. 5.

94 Maroney: "Law and Emotion«, p. 134.

95 Rosenwein: »Problems and Methods«, p. 17.

96 Sabine Müller-Mall: »Entfaltungen des Rechts im Gefühl«, in: Sigrid G. Köhler et al. (eds.): Recht fühlen, Paderborn 2017, pp. 159-175, at pp. 159-161.

97 Similar: Ellerbrock / Kesper-Biermann: „Between Passion and Senses?«, p. 5.

98 Maroney: "Law and Emotion«, p. 131.

99 Volkmar Gessner: "Justiz und Sozialstruktur. Erneute Annäherung an ein altes Thema«, in: Heinz Mohnhaupt / Dieter Simon: Vorträge zur Justizforschung 1, Frankfurt am Main 1992, pp. 387-400, at p. 397.

100 Bandes / Blumenthal: »Emotion and the Law», p. 173.

101 Regina Ogorek: Richterkönig oder Subsumtionsautomat? Zur Justiztheorie im 19. Jahrhundert, Frankfurt am Main 1986, pp. $303 f$.

102 Niklas Luhmann: Das Recht der Gesellschaft, Frankfurt am Main 1993, pp. 195-204.

103 Bandes / Blumenthal: »Emotion and the Law«, p. 168; Müller-Mall: »Entfaltungen«, p. 169.
104 On these procedures from an administrative historical perspective, Pascale Cancik: Verwaltung und Öffentlichkeit in Preußen, Tübingen 2007, pp. 209-374.

105 Brief overview on this debate: Peter Collin: »udging and Conciliation - Differentiations and Complementarities«, in: Max Planck Institute for European Legal History Research Paper Series 4 (2013), online: http://papers.ssrn.com/sol3/papers.cfm?abstract_id=2256508 (1. 8. 2018).

106 See already Josef Kohler: "Schiedsgericht und Aequitas", in: Archiv für Rechts - und Wirtschaftsphilosophie 13 (1919/1920), pp. 6-8.

107 Pascale Cancik: »)Selbst ist das Volkı - Der Ruf nach `Volkstümlichkeit der Verwaltung، in der ersten Hälfte des 19. Jahrhunderts«, in: Der Staat 43 (2004), pp. 298-327.

108 Uwe Zepf: »Mediation im Schatten des Leviathan oder das Verhältnis zwischen hoheitlichem Handeln und Mediation«, in: Die öffentliche Verwaltung 16 (2012), pp. 631-639.

109 Bandes / Blumenthal: »Emotion and the Law«, p. 173.

110 Thomas Groß: Das Kollegialprinzip in der Verwaltungsorganisation, Tübingen 1999.

111 Schützeichel: »Soziologie des Rechtsgefühls«, p. 73.

112 Bandes / Blumenthal: »Emotion and the Law«, pp. $173 \mathrm{f}$. 


\section{Abstract}

In traditional administrative models the public servant is emotionally conceptualized in a specific way, namely as a rationally acting and emotionally abstinent person. However, these are also models of observation that are strongly guided on the one hand by normative ideas and on the other by historical master narratives that focus on the development of a specifically occidental rationality. In particular, the emotional turn in historical science inspires us to take a critical view of such assumptions. But other approaches developed in other scientific disciplines also stimulate us to sharpen our historical view of the emotional aspects of bureaucracy: in jurisprudence "Law and Emotions" and in sociology "Sociology of Emotions". This article presents these scientific approaches and tries to sound out their usefulness for the history of administration. In this way, it also serves as an introduction to this volume of the journal Administory.

\section{About the Authors}

Peter Collin is a senior researcher at the Max-Planck-Institute for European Legal History in Frankfurt /Main. His field of work is the legal history of the 19th and 20th centuries. He currently focusses on modern multinormativity, hybrid regulatory regimes and extrajudicial conflict resolution. He has recently published a study on private-state regulatory structures in the 19th and early 20th centuries (Privatstaatliche Regelungsstrukturen im frühen Industrie- und Sozialstaat. Berlin, Boston 2016).

Robert Garot is Associate Professor, Department of Sociology, John Jay College of Criminal Justice. His book, Who You Claim: Performing Gang Identity in School and on the Streets, published by NYU Press in 2010, has been reviewed in Teacher's College Record and Contemporary Sociology, and it received Honorable Mention for the Robert E. Park Award from the Community and Urban Sociology Section of the American Sociological Association. Between 2007 and 2009, he conducted fieldwork in Tuscany on racialization practices and the experiences of immigrants with the law.

TIMON DE Groot wrote a dissertation on the topic of felony disenfranchisement in nineteenth century Germany at the Humboldt University of Berlin. The dissertation was embedded in the context of the International Max Planck Research School for Moral Economies of Modern Societies and he was also a fellow at the Centre for the History of Emotions at the Max Planck Institute for Human Development in Berlin. Currently, he is a research fellow at the University of Cologne. 